\title{
Analysis of air temperature trends in Bosnia and Herzegovina
}

\author{
Goran TrbićA, Tatjana PopovA*, Slobodan GnjatoA \\ Received: January 11, 2017 | Revised: March 23, 2017 | Accepted: April 5, 2017 \\ DOI: 10.18421/GP21.02-01
}

\begin{abstract}
The paper analyzes the air temperature characteristics in Bosnia and Herzegovina in order to identify recent trends in mean air temperature. Trends in annual, seasonal and monthly mean air temperatures during 1961-2015 periods were determined based on data from sixteen meteorological stations. MAKESENS procedure (Salmi, et al., 2002), which uses the nonparametric Mann-Kendall test and the nonparametric Sen's method, was applied on time series of annual, seasonal and monthly mean air temperatures to assess the trend magnitude and its statistical significance. Given the results, the warming trend is present all over Bosnia and Herzegovina. Significant positive trends in annual and summer temperatures were detected over the entire territory $(p<0.01)$. Positive winter and spring trends are largely significant $(p<0.01$ or $p<0.05)$, whereas autumn trends are low and insignificant. The highest increase was registered in June-August and December-January periods. In some areas, a low negative trend was present in September and November. A significant positive correlation between East-Atlantic pattern index and temperature was determined over the entire territory of Bosnia and Herzegovina throughout the year. Winter and spring temperatures were also significantly related to the North Atlantic Oscillation index and Arctic Oscillation index, respectively.
\end{abstract}

Keywords: mean monthly, seasonal and annual temperatures, temperature trend, MAKESENS, climate change, Northern Hemisphere teleconnection patterns, Bosnia and Herzegovina.

\section{Introduction}

In recent years, numerous studies have analyzed temperature variations due to the anticipated impact of climate change on natural and human systems. Global warming of the climate system is unequivocal and many of the changes in the second half of the 2oth century have not been observed in recent decades and centuries (IPCC, 2014). Monthly and seasonal surface temperature reconstructions for Europe ranging back to 1500 showed that the late 20 th- and early 21st-century climate was very likely $(\mathrm{p}<0.05)$ warmer than that of any time during the past 500 years (Luterbacher, et al., 2004).

In the last hundred years, during which time the climate system has been warmed about $0.6^{\circ} \mathrm{C}$, two major warm-up periods were recorded - between 1910 and 1945 and since 1976 to date, noting that the warming rate in the latter period was as twice as large (IPCC, 2014). Global annual temperature has increased since 1880 at an average rate of $0.07^{\circ} \mathrm{C}$ per decade (Hansen, et al., 2006). Such low global warming with large fluctuations up to 1975 had been followed by rapid warming at a rate of $0.2^{\circ} \mathrm{C}$ per decade (Hansen, et al., 2006; NOAA, 2016). The fastest warming in recent decades occurred in northern mid-latitudes (Fei, et al., 2014). According to Luterbacher, et al. (2004), the last thirty years $\left(1974^{-2003}\right)$ were the warmest 30-year period of the last half-millennium. The global surface and lower-troposphere land and ocean temperature analyses showed a consistent global warming trend dur-

\footnotetext{
A University of Banja Luka, Faculty of Sciences, Dr. Mladena Stojanovića 2, 78000 Banja Luka, the Republic of Srpska, Bosnia and Herzegovina; tatjanapopov@yahoo.com

* Corresponding author: Tatjana Popov, e-mail: tatjanapopov@yahoo.com
} 
ing 1979-2010 periods (Foster, Rahmstorf, 2011). The past three decades have been the warmest during the instrumental period. Each decade was successively warmer than the previous one, so that the first decade of 21st century was the warmest since 1850 (Hartmann, et al., 2013; IPCC, 2014). Fifteen out of sixteen hottest years in the instrumental temperature measurement period were recorded in this century - 2015 was the hottest year globally and the 2011-2015 pentad was the warmest five-year period (WMO, 2016; NOAA, 2016). Most regions of the world (including Europe) showed a significant decrease in the annual occurrence of cold nights and cold days and a significant increase in the annual occurrence of warm nights and warm days (Alexander, et al., 2006; Klein Tank, Können, 2003).

During the 2oth century, air temperature increased in most parts of Europe, but warming rate was the highest in the last quarter of the century (Kovats, et al., 2014). In addition, 2014 was the warmest year at the continental scale. Studies showed that the warming of the climate system is present in the Southeast Europe region. The annual and seasonal air temperature analyses in Serbia, Croatia, Slovenia, Montenegro, and Greece showed pronounced and mostly significant positive trends in vast majority of areas in the second half of 2oth and the beginning of 21st century (Ducić, et al., 2009; Ducić, et al., 2008; Bajat, et al., 2015; Branković, et al., 2013; Milošević, et al., 2013; Burić, et al., 2014; Mamara, et al., 2016). The overall positive trends in annual air temperatures are mainly caused by the high and statistically significant positive summer trends. The highest trend values are obtained for summer, and then for winter and spring temperatures. Autumn temperatures are subjected to small and mostly positive changes, though mainly insignificant. The climate system warming is also manifested in pronounced trends of all temperature extremes -in the positive trends of warm temperature indices (warm days and warm nights, heat waves, etc.) and in negative trends of cold temperature indices (cold days and cold nights, cold waves, etc.) (Branković, et al., 2013).

Previous studies in some regions of Bosnia and Herzegovina (Trbić, Bajić, 2011; Trbić, 2013; Popov, Trbić, 2015; Popov, Živak, 2016) suggested that a positive temperature trend was also present over the territory of Bosnia and Herzegovina. Cited studies primarily focused on comparative analyses of the temperature change between two observed periods those were mainly changes in later periods compared to the standard climatological period.

The aim of this paper is to determine trends in annual, seasonal and monthly mean air temperatures and its significance, and to specify the areas with the most pronounced trends. In order to evaluate the observed trends, temperature data are correlated with large-scale atmospheric circulation patterns.

\section{Data and methods}

The analysis of trends in annual, seasonal and monthly air temperatures during 1961-2015 periods was carried out using data of mean monthly temperatures from sixteen meteorological stations located in all parts of Bosnia and Herzegovina (Figure 1).The selected meteorological stations covered all three physical macro regions of Bosnia and Herzegovina: Peripannonian, Dinaric and Submediterranean, and a wide range of altitudes - from $97 \mathrm{~m}$ to $2067 \mathrm{~m}$ above sea level (relative height difference being $1970 \mathrm{~m}$ ). Data were collected from the Meteorological yearbook of the Federal Hydrometeorological Institute Sarajevo and from documentation of the Republic Hydrometeorological Service of the Republic of Srpska. Given that there were interruptions in measurements in the war and post-war periods at the majority of meteorological stations, extrapolation of missing data was carried out using data from the nearest station with available measurements in the corresponding period.

The recent temperature variability in Bosnia and Herzegovina has been determined by trends in annual, seasonal and monthly mean air temperatures. MAKESENS procedure created by Salmi, et al. (2002) was applied on annual, seasonal and monthly mean air temperature time series to assess magnitude and statistical significance of trends. The procedure is based on the nonparametric Mann-Kendall test for determing a trend in the time series and the nonparametric Sen's method for the trend magnitude estimate (Salmi, et al., 2002). The Mann-Kendall trend test is a widely used nonparametric instrument to detect a trend in a data series. Sen's nonparametric estimator of slope uses a linear model for trend magnitude estimate (Salmi, et al., 2002). Statistical significance of the observed trends was defined at the level of $95 \%$ and $99 \%$. Then, the average annual and seasonal mean air temperatures in two periods - the World Meteorological Organization current standard normal period (1961-1990) and the last thirty years (1986-2015) were compared and analyzed in order to further confirm the observed trends in the studied area. Thet-test was used to test the statistical significance of the differences in air temperature in the two observed periods.

In order to evaluate the observed temperature trends, the correlation analysis with the dominant Northern Hemisphere teleconnection patterns was performed. The primary modes of atmospheric circulation variability over the North Atlantic that impact seasonal climates over Europe - the North At- 


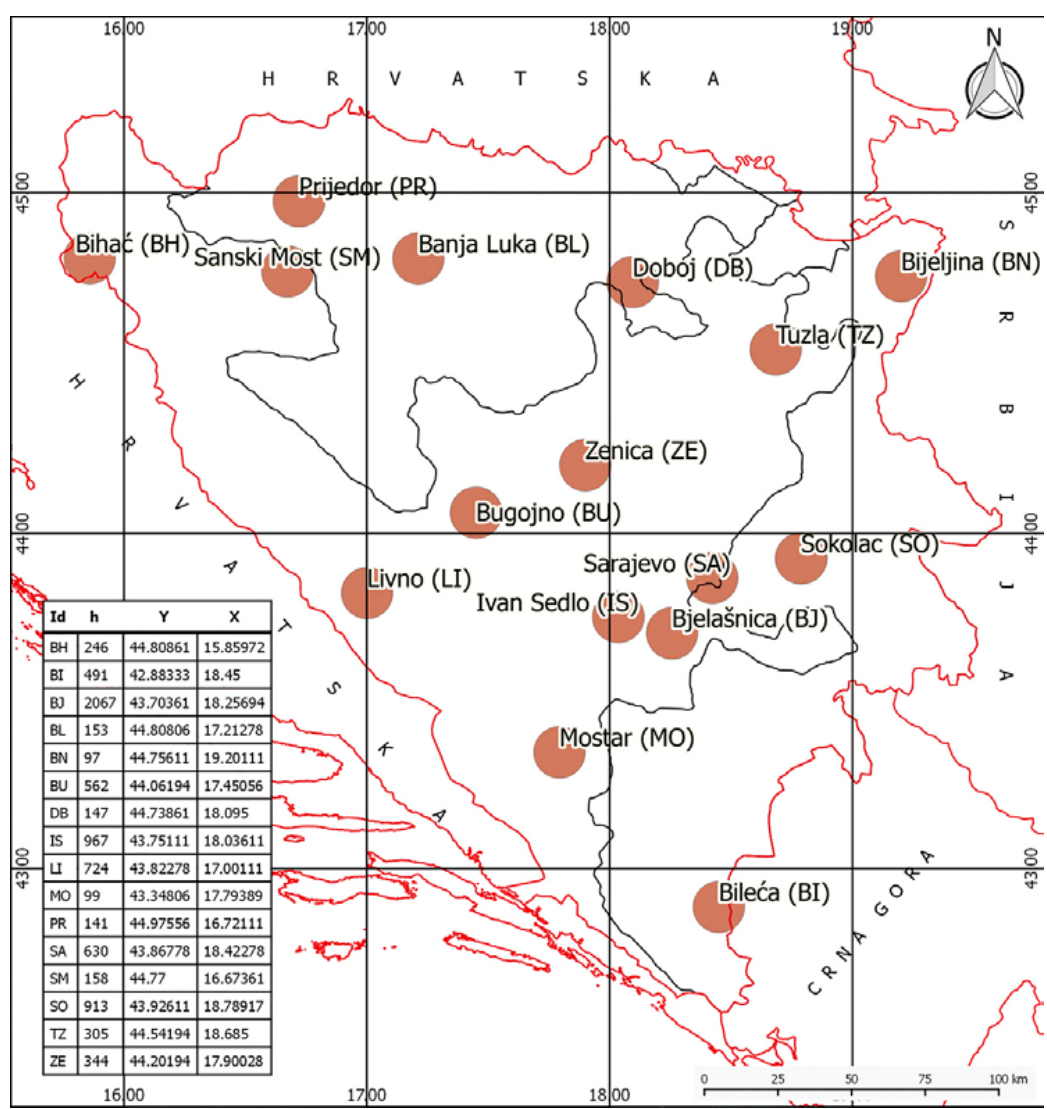

Figure 1. The geographical locations of the studied meteorological stations in Bosnia and Herzegovina and their coordinates

lantic Oscillation (NAO) and the East-Atlantic (EA) pattern - have been analyzed. In addition to this teleconnection patterns, the influence of Arctic Oscillation $(\mathrm{AO})$ on temperature in Bosnia and Herzegovina was also evaluated. Data on teleconnection patterns indices were collected from NOAA National Weather Service Climate Prediction Center (Internet 1). The Pearson correlation coefficients were calculated on monthly and seasonal levels for each station and for state average temperatures.

\section{Results and discussion}

The annual and seasonal mean air temperatures in Bosnia and Herzegovina are shown in Table 1. The average annual temperature decreases from $10.5^{-11.5^{\circ} \mathrm{C}}$ as we move from north towards the high mountainous area in the central part of Bosnia and Herzegovina. The average temperature at the highest-located station in Bosnia and Herzegovina (Bjelašnica) is $1.5^{\circ} \mathrm{C}$. The lowland area of Herzegovina region in the south is characterized by the highest annual temperatures (e.g. Mostar $15.0^{\circ} \mathrm{C}$ ). Winter is the coldest season over the entire study area. The coldest winters are in the high mountain areas (Bjelašnica $-6.0^{\circ} \mathrm{C}$ and Sokolac $-2.7^{\circ} \mathrm{C}$ ) and the warmest in Herzegovina (Mostar $6.1^{\circ} \mathrm{C}$ and Bileća $3.9^{\circ} \mathrm{C}$ ). Slight differences in average spring and autumn temperatures are present in the northern part of the territory, whereas autumn is warmer than spring in the mountainous area and in Herzegovina (e.g. Bjelašnica $-0.4^{\circ} \mathrm{C}$ and $2.8^{\circ} \mathrm{C}$, and Mostar $15.5^{\circ} \mathrm{C}$ and $14.1^{\circ} \mathrm{C}$ ). Summer is the warmest season in Bosnia and Herzegovina, with average temperatures ranging from $9.4^{\circ} \mathrm{C}$ and $16.0^{\circ} \mathrm{C}$ in Bjelašnica

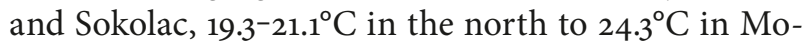
star. The average temperatures in growing season are

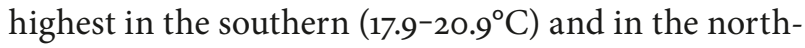

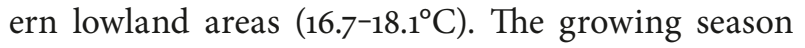
average temperature at altitudes higher than $900 \mathrm{~m}$ ranges from only $1.5^{\circ} \mathrm{C}$ to $7.5^{\circ} \mathrm{C}$.

The estimated trends in mean air temperature indicate that the climate system warming is present over the entire territory of Bosnia and Herzegovina. Annual temperature trends are positive and significant $(\mathrm{p}<0.01)$, with the highest frequency of increase within the $0.3^{-} 0.4^{\circ} \mathrm{C}$ range per decade (Figure2). The annual temperature increase is higher in the north, i.e. in Posavina and Semberija regions, in comparison with the high mountainous area. On Bjelašnica Mountain and in high mountainous areas of Herzegovina, the annual temperature has increased $0.2^{\circ} \mathrm{C}$ per decade. The highest annual temperature increase occurred in Banja Luka ( $0.5^{\circ} \mathrm{C}$ per decade), probably due to influence of the urban heat island. 
Table 1. Annual and seasonal mean air temperatures in Bosnia and Herzegovina in 1961-2015 $\left({ }^{\circ} \mathrm{C}\right)$

\begin{tabular}{|c|c|c|c|c|c|c|}
\hline Station & Winter & Spring & Summer & Autumn & Growing season & Year \\
\hline BH & 1.8 & 11.0 & 19.9 & 11.4 & 17.0 & 11.0 \\
\hline SM & 1.0 & 10.7 & 19.6 & 10.8 & 16.7 & 10.5 \\
\hline PR & 1.0 & 11.3 & 20.6 & 11.2 & 17.6 & 11.0 \\
\hline BL & 1.3 & 11.4 & 20.6 & 11.3 & 17.6 & 11.2 \\
\hline DB & 1.2 & 11.3 & 20.3 & 11.3 & 17.4 & 11.0 \\
\hline TZ & 0.9 & 10.6 & 19.3 & 10.7 & 16.5 & 10.4 \\
\hline BN & 1.3 & 11.8 & 21.1 & 11.7 & 18.1 & 11.5 \\
\hline ZE & 0.9 & 10.9 & 19.8 & 10.9 & 16.9 & 10.6 \\
\hline BU & 0.0 & 9.3 & 18.2 & 9.7 & 15.3 & 9.3 \\
\hline SO & -2.7 & 6.8 & 16.0 & 7.5 & 13.1 & 6.9 \\
\hline SA & 0.6 & 9.8 & 18.8 & 10.5 & 16.0 & 9.9 \\
\hline BJ & -6.0 & -0.4 & 9.4 & 2.8 & 6.3 & 1.5 \\
\hline IS & -1.3 & 7.1 & 16.0 & 8.4 & 13.3 & 7.5 \\
\hline LI & 0.6 & 8.9 & 18.3 & 9.8 & 15.3 & 9.4 \\
\hline BI & 3.9 & 11.3 & 21.1 & 12.9 & 17.9 & 12.3 \\
\hline MO & 6.1 & 14.1 & 24.3 & 15.5 & 20.9 & 15.0 \\
\hline
\end{tabular}
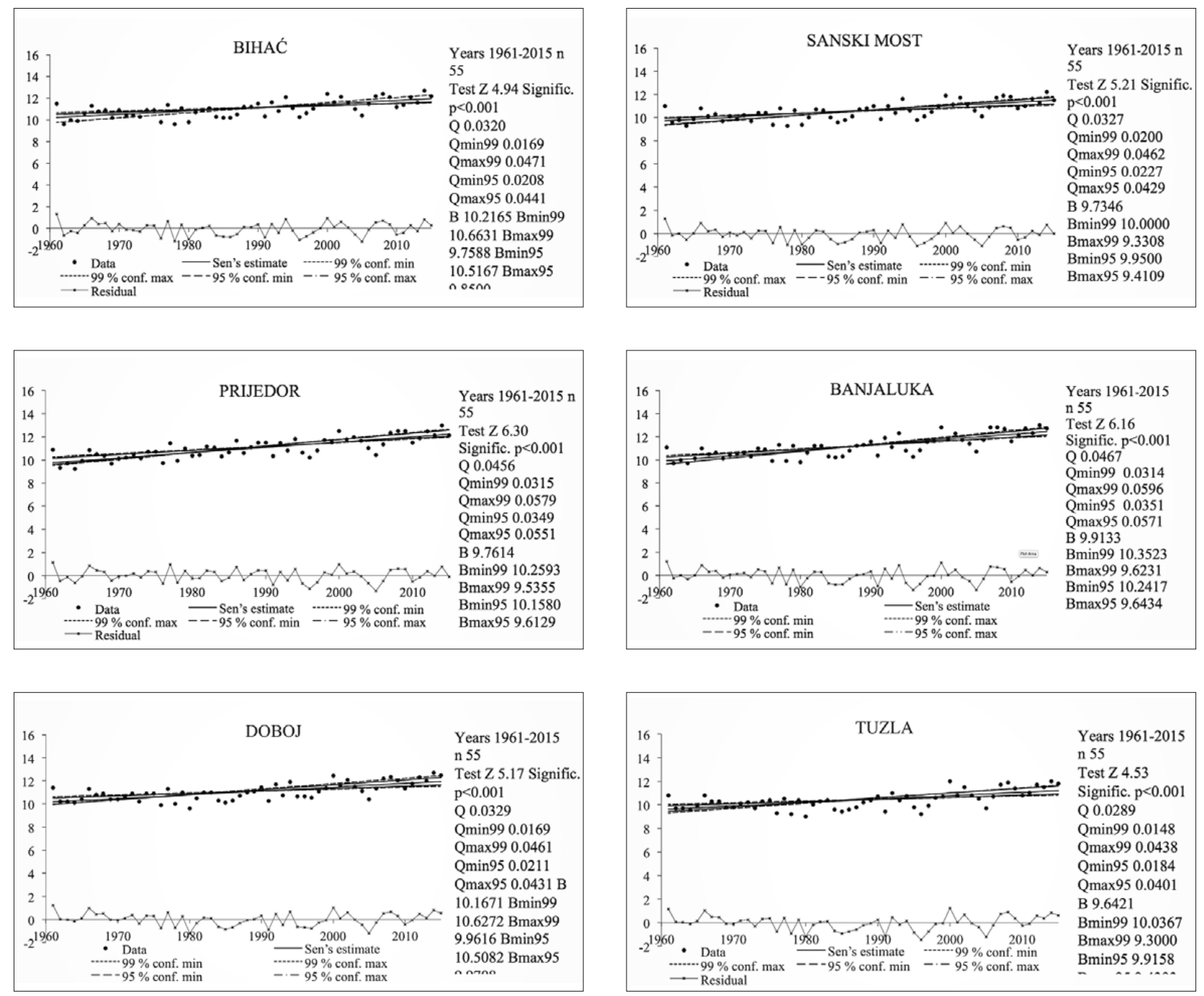

Figure 2. Linear trend in annual mean air temperatures in Bosnia and Herzegovina in 1961-2015 

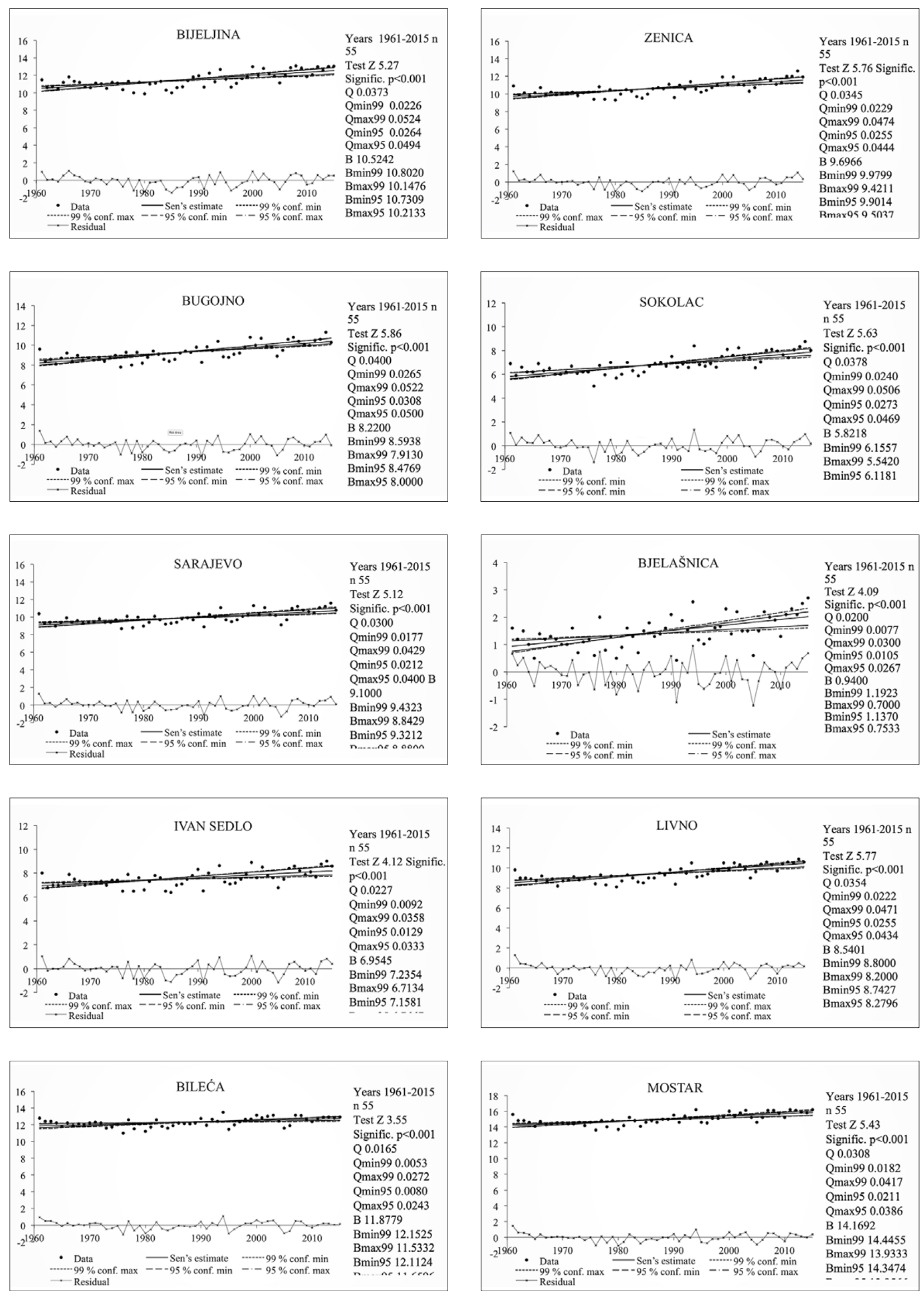

Figure 2. Linear trend in annual mean air temperatures in Bosnia and Herzegovina in 1961-2015 

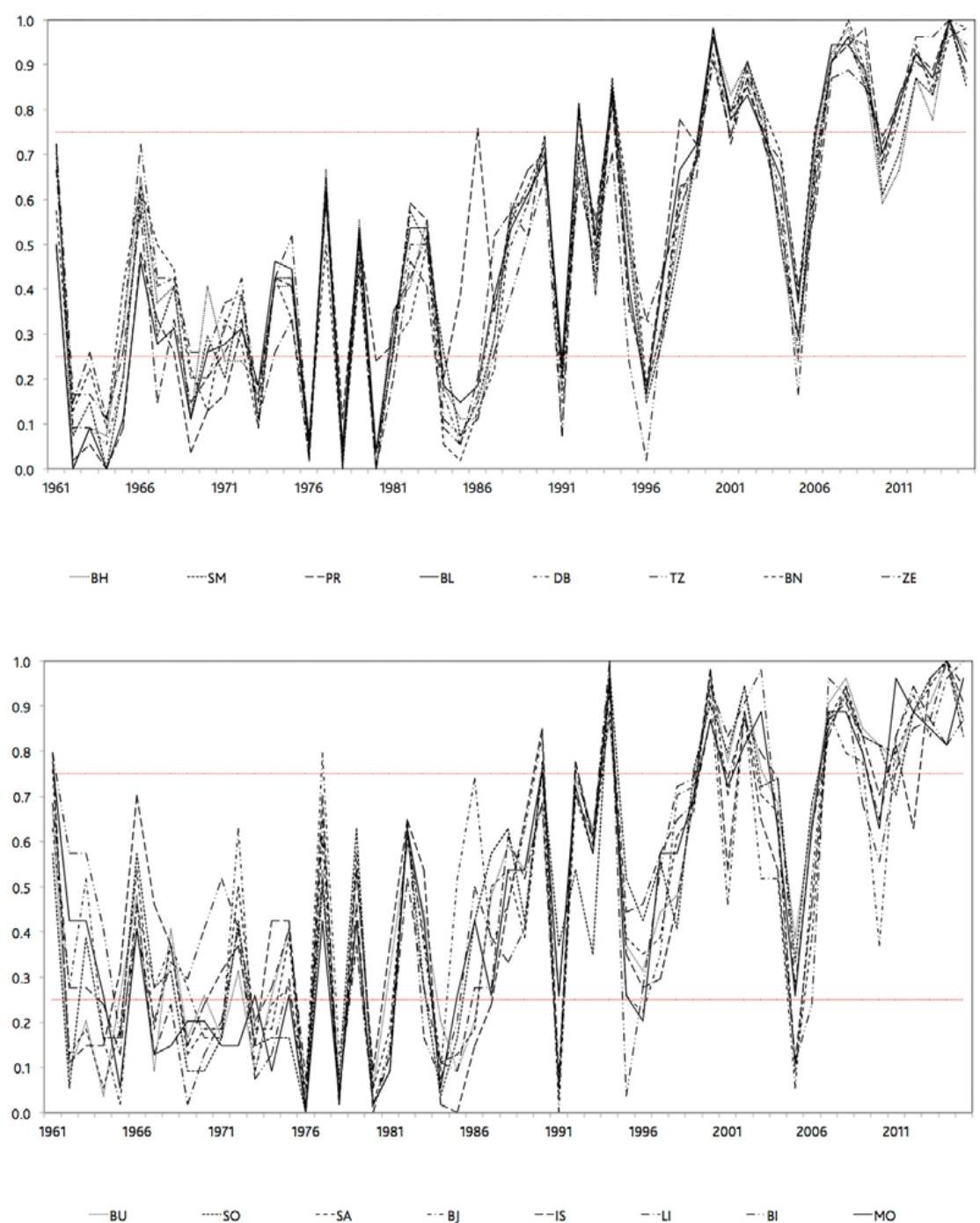

Figure 3. Annual mean air temperature percentiles in Bosnia and Herzegovina in 1961-2015

The analysis of annual mean temperature percentiles suggests a more pronounced warming trend since 1990 os (Figure 3). Since the beginning of 1990s, only one or two years were below 25 th percentile. On the other hand, every other year was above 75 th percentile on average. At the majority of stations, almost every fourth year was above the goth percentile and half the stations registered not a single occurrence below the 1oth percentile (at the other half, only one or two years, mainly 1996 and 2005). Since 1990, 16-21 years were above 9oth percentile of the standard climatological period (except for Ivan Sedlo and Bjelašnica, 11-13).

Nine out of ten warmest years in the observed period have been recorded since 2000 (only 1994 is among the ten warmest). In most areas, 2014 was the hottest year. Among the warmest years (above 9oth percentile) in most areas were also the following years: 2000 , $2007,2008,2012$, and 2015. The largest number of years below 1oth percentile was in 1976-1980 pentad (1976,
1978, and 1980) and in 1961-1965 pentad in the northern part of the territory $(1962,1963$, and 1964). Since 1990, five pentads have been the hottest pentads in the analyzed period. Particularly warm were three pentads in the 21st century. It should be noted that the last pentad (2011-2015) was by far the warmest $-0.8^{-}-2.0^{\circ} \mathrm{C}$ warmer than the standard climatological period average.

A positive trend in mean air temperature has been registered over the entire territory in all seasons (except in Bileća in autumn) (Table 2 and Figure 4). Although warming is apparent in all seasons, the trend is most prominent in summer, and then in winter and spring. In autumn, only a slight increase has been observed. The overall positive trends in the annual air temperatures are mainly caused by the significant $(\mathrm{p}<0.01)$ positive summer trends present all over the territory of Bosnia and Herzegovina. At majority of stations, the temperature increased in this season by $0.4^{-0} .6^{\circ} \mathrm{C}$ per decade. The highest trend values have Figure 2. Linear trend in annual mean air temperatures in Bosnia and Herzegovina in 1961-2015 
Table 2. Decadal trends in annual and seasonal mean air temperatures in Bosnia and Herzegovina in 1961-2015 ( ${ }^{\circ} \mathrm{C}$ per decade)

\begin{tabular}{|c|c|c|c|c|c|c|}
\hline Station & Winter & Spring & Summer & Autumn & Growing season & Year \\
\hline BH & 0.25 & $\mathbf{0 . 3 0}$ & $\mathbf{0 . 4 5}$ & 0.14 & $\mathbf{0 . 3 3}$ & $\mathbf{0 . 3 2}$ \\
\hline SM & 0.32 & $\mathbf{0 . 2 8}$ & $\mathbf{0 . 4 4}$ & 0.14 & $\mathbf{0 . 3 3}$ & $\mathbf{0 . 3 3}$ \\
\hline PR & $\mathbf{0 . 4 0}$ & $\mathbf{0 . 4 4}$ & $\mathbf{0 . 5 9}$ & 0.21 & $\mathbf{0 . 4 8}$ & $\mathbf{0 . 4 6}$ \\
\hline BL & $\mathbf{0 . 4 6}$ & $\mathbf{0 . 3 8}$ & $\mathbf{0 . 6 1}$ & $\mathbf{0 . 3 0}$ & $\mathbf{0 . 4 9}$ & $\mathbf{0 . 4 7}$ \\
\hline DB & 0.36 & $\mathbf{0 . 2 4}$ & $\mathbf{0 . 4 4}$ & 0.15 & $\mathbf{0 . 3 3}$ & $\mathbf{0 . 3 3}$ \\
\hline TZ & 0.32 & 0.24 & $\mathbf{0 . 4 0}$ & 0.12 & $\mathbf{0 . 3 0}$ & $\mathbf{0 . 2 9}$ \\
\hline BN & 0.36 & $\mathbf{0 . 3 5}$ & $\mathbf{0 . 6 1}$ & 0.19 & $\mathbf{0 . 4 5}$ & $\mathbf{0 . 3 7}$ \\
\hline ZE & $\mathbf{0 . 3 8}$ & $\mathbf{0 . 2 9}$ & $\mathbf{0 . 5 4}$ & 0.20 & $\mathbf{0 . 3 9}$ & $\mathbf{0 . 3 4}$ \\
\hline BU & $\mathbf{0 . 4 3}$ & $\mathbf{0 . 3 3}$ & $\mathbf{0 . 5 6}$ & 0.23 & $\mathbf{0 . 4 3}$ & $\mathbf{0 . 4 0}$ \\
\hline SO & $\mathbf{0 . 5 4}$ & $\mathbf{0 . 2 6}$ & $\mathbf{0 . 5 1}$ & 0.24 & $\mathbf{0 . 3 7}$ & $\mathbf{0 . 3 8}$ \\
\hline SA & 0.34 & 0.23 & $\mathbf{0 . 4 9}$ & 0.16 & $\mathbf{0 . 3 3}$ & $\mathbf{0 . 3 0}$ \\
\hline BJ & 0.04 & 0.14 & $\mathbf{0 . 4 1}$ & 0.08 & $\mathbf{0 . 2 6}$ & $\mathbf{0 . 2 0}$ \\
\hline IS & 0.31 & 0.19 & $\mathbf{0 . 3 0}$ & 0.11 & $\mathbf{0 . 1 8}$ & $\mathbf{0 . 2 3}$ \\
\hline LI & 0.28 & $\mathbf{0 . 2 9}$ & $\mathbf{0 . 5 4}$ & 0.26 & $\mathbf{0 . 4 2}$ & $\mathbf{0 . 3 5}$ \\
\hline BI & 0.11 & 0.15 & $\mathbf{0 . 3 6}$ & -0.01 & $\mathbf{0 . 2 5}$ & $\mathbf{0 . 1 6}$ \\
\hline MO & 0.24 & $\mathbf{0 . 3 0}$ & $\mathbf{0 . 5 2}$ & 0.14 & $\mathbf{0 . 3 9}$ & $\mathbf{0 . 3 1}$ \\
\hline
\end{tabular}

Note: Statistically significant at $p<0.01$ (bold) and $p<0.05$ (italic)

been estimated for Banja Luka and Bijeljina area. The summer temperature increase was lower only in high mountainous areas of Herzegovina. The estimated winter and spring temperature trends are mostly significant $(\mathrm{p}<0.01$ or $\mathrm{p}<0.05)$ with the highest frequency of increase in the range of $0.3^{-} 0.5^{\circ} \mathrm{C}$ and $0.2^{-} 0.4^{\circ} \mathrm{C}$ per decade, respectively. Warming in these seasons is smaller and generally insignificant only in Bileća and
Bjelašnica area. It is interesting to note that the highest and lowest winter temperature increases have been recorded at two highest-located stations - Sokolac $0.54^{\circ} \mathrm{C}$ per decade, and Bjelašnica $0.04^{\circ} \mathrm{C}$ per decade. Autumn temperatures are subjected to low and mainly insignificant positive trends $\left(0.1^{-} 0.2^{\circ} \mathrm{C}\right.$ per decade). The observed trends are significant only in a few areas - Banja Luka, Prijedor, Bugojno, Sokolac, and Liv-

Table 3. Annual and seasonal mean air temperatures in Bosnia and Herzegovina in 1961-1990 (a) and 1986-2015 (b) ( $\left.{ }^{\circ} \mathrm{C}\right)$

\begin{tabular}{|c|c|c|c|c|c|c|c|c|c|c|c|c|c|}
\hline \multirow{2}{*}{ Station } & \multicolumn{2}{|c|}{ Winter } & \multicolumn{2}{|c|}{ Spring } & \multicolumn{2}{c|}{ Summer } & \multicolumn{2}{c|}{ Autumn } & \multicolumn{2}{|c|}{ Growing season } & \multicolumn{2}{|c|}{ Year } \\
\cline { 2 - 17 } & $\mathrm{a}$ & $\mathrm{b}$ & $\mathrm{a}$ & $\mathrm{b}$ & $\mathrm{a}$ & $\mathrm{b}$ & $\mathrm{a}$ & $\mathrm{b}$ & $\mathrm{a}$ & $\mathrm{b}$ & $\mathrm{a}$ & $\mathrm{b}$ \\
\hline $\mathrm{BH}$ & 1.4 & 2.3 & 10.6 & 11.3 & 19.2 & 20.5 & 11.2 & 11.6 & 16.5 & 17.5 & 10.6 & 11.4 \\
\hline SM & 0.6 & 1.5 & 10.3 & 11.0 & 18.9 & 20.3 & 10.6 & 11.0 & 16.2 & 17.2 & 10.1 & 11.0 \\
\hline PR & 0.4 & 1.6 & 10.8 & 11.8 & 19.8 & 21.3 & 10.9 & 11.5 & 17.0 & 18.2 & 10.5 & 11.6 \\
\hline BL & 0.8 & 2.0 & 10.9 & 11.8 & 19.7 & 21.4 & 10.9 & 11.7 & 16.9 & 18.2 & 10.6 & 11.7 \\
\hline DB & 0.8 & 1.8 & 11.0 & 11.6 & 19.6 & 20.9 & 11.0 & 11.5 & 17.0 & 17.9 & 10.6 & 11.4 \\
\hline TZ & 0.6 & 1.3 & 10.3 & 10.8 & 18.6 & 20.0 & 10.5 & 10.9 & 16.1 & 17.0 & 10.0 & 10.7 \\
\hline BN & 0.9 & 1.9 & 11.3 & 12.2 & 20.2 & 22.0 & 11.4 & 11.9 & 17.5 & 18.8 & 10.9 & 12.0 \\
\hline ZE & 0.5 & 1.3 & 10.5 & 11.2 & 18.9 & 20.6 & 10.6 & 11.2 & 16.3 & 17.5 & 10.1 & 11.1 \\
\hline BU & -0.5 & 0.5 & 8.9 & 9.7 & 17.3 & 19.0 & 9.4 & 10.1 & 14.7 & 15.9 & 8.8 & 9.8 \\
\hline SO & -3.2 & -2.0 & 6.4 & 7.1 & 15.2 & 16.7 & 7.1 & 7.9 & 12.6 & 13.6 & 6.4 & 7.4 \\
\hline SA & 0.3 & 1.0 & 9.6 & 10.1 & 18.1 & 19.5 & 10.2 & 10.7 & 15.5 & 16.4 & 9.5 & 10.3 \\
\hline BJ & -6.0 & -5.9 & -0.6 & -0.3 & 8.8 & 10.0 & 2.7 & 2.9 & 6.0 & 6.7 & 1.2 & 1.7 \\
\hline IS & -1.7 & -1.0 & 6.8 & 7.3 & 15.6 & 16.5 & 8.2 & 8.5 & 12.9 & 13.6 & 7.3 & 7.8 \\
\hline LI & 0.3 & 1.0 & 8.4 & 9.3 & 17.5 & 19.1 & 9.4 & 10.1 & 14.7 & 15.8 & 8.9 & 9.9 \\
\hline BI & 3.8 & 4.2 & 11.1 & 11.5 & 20.5 & 21.7 & 12.8 & 12.9 & 17.5 & 18.3 & 12.0 & 12.6 \\
\hline MO & 5.9 & 6.5 & 13.6 & 14.5 & 23.5 & 25.1 & 15.3 & 15.7 & 20.3 & 21.5 & 14.6 & 15.4 \\
\hline
\end{tabular}



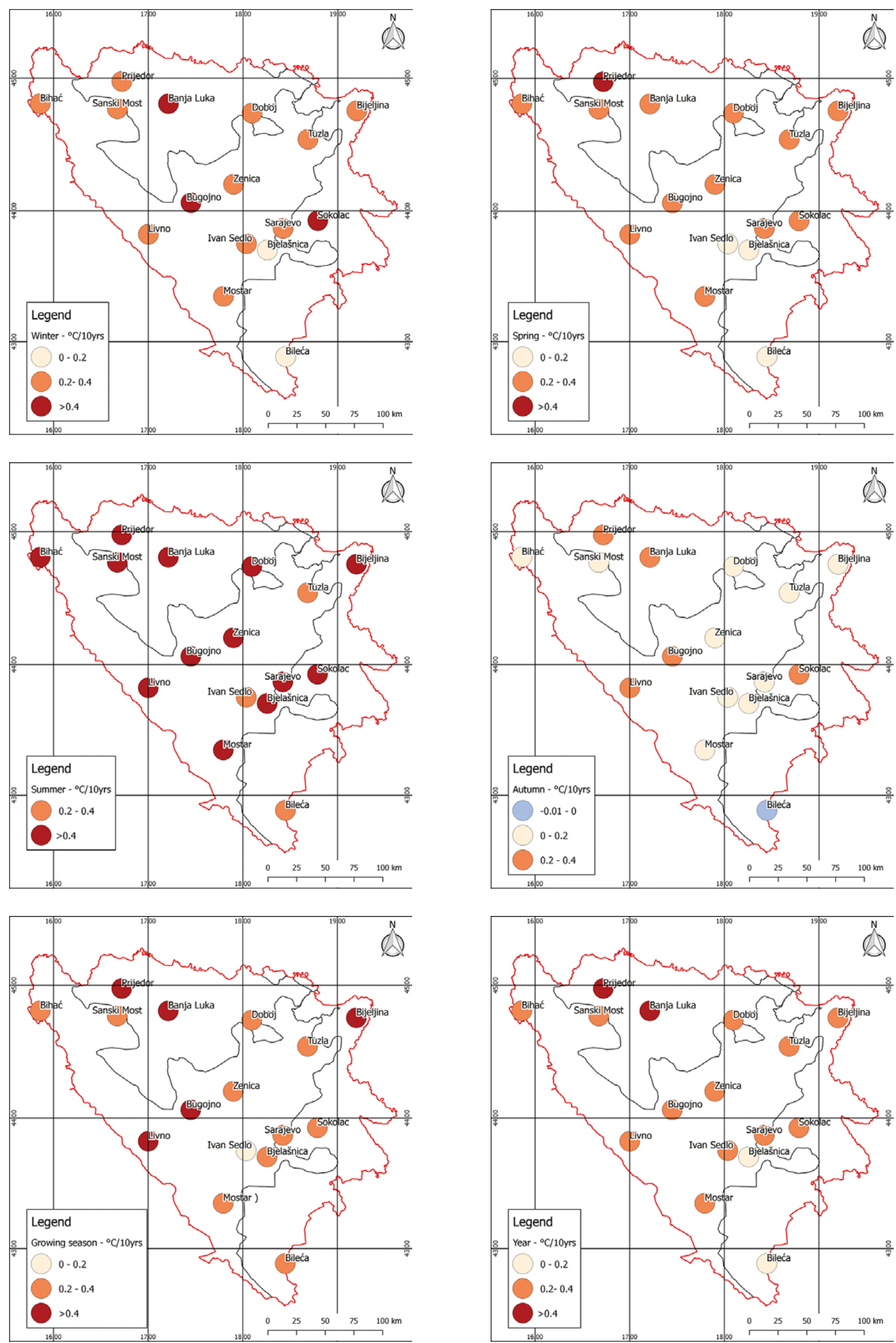

Figure 4. Decadal trends in annual and seasonal mean air temperatures in Bosnia and Herzegovina in 1961-2015 
Table 4. Difference between average annual and seasonal mean air temperatures in Bosnia and Herzegovina in 19862015 relative to $1961-1990\left({ }^{\circ} \mathrm{C}\right)$

\begin{tabular}{|c|c|c|c|c|c|c|}
\hline Station & Winter & Spring & Summer & Autumn & Growing season & Year \\
\hline $\mathrm{BH}$ & 0.9 & 0.7 & 1.3 & 0.4 & 0.9 & 0.8 \\
\hline SM & 0.9 & 0.7 & 1.3 & 0.4 & 1.0 & 0.8 \\
\hline PR & 1.2 & 1.0 & 1.5 & 0.5 & 1.2 & 1.1 \\
\hline $\mathrm{BL}$ & 1.2 & 0.9 & 1.7 & 0.8 & 1.3 & 1.1 \\
\hline DB & 1.0 & 0.6 & 1.3 & 0.4 & 0.9 & 0.8 \\
\hline $\mathrm{TZ}$ & 0.7 & 0.5 & 1.3 & 0.4 & 0.9 & 0.7 \\
\hline $\mathrm{BN}$ & 1.0 & 0.9 & 1.9 & 0.6 & 1.3 & 1.1 \\
\hline ZE & 0.8 & 0.7 & 1.6 & 0.7 & 1.2 & 0.9 \\
\hline $\mathrm{BU}$ & 1.0 & 0.8 & 1.6 & 0.7 & 1.2 & 1.0 \\
\hline SO & 1.2 & 0.6 & 1.5 & 0.8 & 1.0 & 1.0 \\
\hline SA & 0.7 & 0.5 & 1.4 & 0.5 & 0.9 & 0.8 \\
\hline BJ & 0.1 & 0.3 & 1.3 & 0.2 & 0.8 & 0.5 \\
\hline IS & 0.7 & 0.4 & 1.0 & 0.3 & 0.6 & 0.6 \\
\hline LI & 0.7 & 0.8 & 1.6 & 0.7 & 1.2 & 0.9 \\
\hline $\mathrm{BI}$ & 0.4 & 0.4 & 1.2 & 0.1 & 0.8 & 0.5 \\
\hline $\mathrm{MO}$ & 0.6 & 0.8 & 1.6 & 0.4 & 1.1 & 0.8 \\
\hline
\end{tabular}

Note: Statistically significant at $p<0.01$ (bold) and $p<0.05$ (italic)

no. A low negative trend is found only in Bileća area (-o.01 ${ }^{\circ} \mathrm{C}$ per decade). In growing season, significant $(\mathrm{p}<0.01)$ positive trends (in the range of $0.3^{-} 0.5^{\circ} \mathrm{C}$ per decade) are present all over the study area.

The comparative analyses of annual mean air temperatures in the last thirty years (1986-2015) have showed statistically significant $(\mathrm{p}<0.01)$ difference relative to the standard climatological period (1961-1990) at all analyzed stations (Table 3 and Table 4). This also confirms the observed warming trend. The highest increase is present over the northern part of the territory and in Sokolac area, where average annual temperatures in the $1986-2015$ periods were $0.8^{-1.1{ }^{\circ}} \mathrm{C}$ higher relative to reference period averages.

Seasonal mean air temperatures also shifted towards higher values in the latter period compared to

Table 5. Decadal trends in monthly mean air temperatures in Bosnia and Herzegovina in 1961-2015 ( ${ }^{\circ} \mathrm{C}$ per decade)

\begin{tabular}{|c|c|c|c|c|c|c|c|c|c|c|c|c|}
\hline Station & I & II & III & IV & V & VI & VII & VIII & IX & X & XI & XII \\
\hline BH & 0.53 & 0.00 & 0.27 & 0.32 & $\mathbf{0 . 3 2}$ & $\mathbf{0 . 3 9}$ & $\mathbf{0 . 5 0}$ & $\mathbf{0 . 5 6}$ & -0.05 & 0.20 & 0.25 & $\mathbf{0 . 4 8}$ \\
\hline SM & 0.50 & 0.12 & 0.26 & 0.31 & $\mathbf{0 . 3 3}$ & $\mathbf{0 . 3 7}$ & $\mathbf{0 . 5 0}$ & $\mathbf{0 . 5 8}$ & 0.04 & 0.19 & 0.14 & $\mathbf{0 . 4 1}$ \\
\hline PR & $\mathbf{0 . 6 4}$ & 0.20 & 0.44 & $\mathbf{0 . 4 4}$ & $\mathbf{0 . 4 7}$ & $\mathbf{0 . 5 0}$ & $\mathbf{0 . 6 9}$ & $\mathbf{0 . 6 9}$ & 0.13 & 0.21 & 0.24 & $\mathbf{0 . 5 2}$ \\
\hline BL & $\mathbf{0 . 7 0}$ & 0.24 & 0.40 & 0.38 & $\mathbf{0 . 4 1}$ & $\mathbf{0 . 5 0}$ & $\mathbf{0 . 6 8}$ & $\mathbf{0 . 8 0}$ & 0.24 & 0.37 & 0.29 & $\mathbf{0 . 5 0}$ \\
\hline DB & $\mathbf{0 . 6 5}$ & 0.17 & 0.27 & 0.24 & 0.27 & $\mathbf{0 . 3 3}$ & $\mathbf{0 . 5 0}$ & $\mathbf{0 . 5 6}$ & 0.04 & 0.25 & 0.15 & 0.41 \\
\hline TZ & 0.50 & 0.13 & 0.23 & 0.26 & 0.24 & 0.25 & $\mathbf{0 . 5 0}$ & $\mathbf{0 . 5 6}$ & 0.02 & 0.21 & 0.13 & 0.33 \\
\hline BN & $\mathbf{0 . 6 6}$ & 0.10 & 0.33 & 0.38 & $\mathbf{0 . 3 7}$ & $\mathbf{0 . 5 0}$ & $\mathbf{0 . 6 8}$ & $\mathbf{0 . 7 3}$ & 0.07 & 0.22 & 0.19 & 0.42 \\
\hline ZE & 0.44 & 0.16 & 0.31 & 0.30 & $\mathbf{0 . 3 1}$ & $\mathbf{0 . 4 6}$ & $\mathbf{0 . 5 8}$ & $\mathbf{0 . 6 7}$ & 0.16 & 0.25 & 0.15 & 0.35 \\
\hline BU & 0.46 & 0.24 & 0.34 & 0.33 & $\mathbf{0 . 3 6}$ & $\mathbf{0 . 5 1}$ & $\mathbf{0 . 6 2}$ & $\mathbf{0 . 6 5}$ & 0.16 & 0.34 & 0.15 & 0.43 \\
\hline SO & $\mathbf{0 . 7 6}$ & 0.36 & 0.30 & 0.28 & 0.27 & $\mathbf{0 . 3 9}$ & $\mathbf{0 . 5 5}$ & $\mathbf{0 . 6 1}$ & 0.13 & 0.31 & 0.18 & 0.41 \\
\hline SA & 0.43 & 0.09 & 0.22 & 0.26 & 0.22 & $\mathbf{0 . 3 9}$ & $\mathbf{0 . 5 0}$ & $\mathbf{0 . 6 0}$ & 0.05 & 0.22 & 0.11 & 0.33 \\
\hline BJ & 0.16 & 0.01 & 0.07 & 0.20 & 0.25 & $\mathbf{0 . 3 3}$ & $\mathbf{0 . 4 7}$ & $\mathbf{0 . 5 0}$ & -0.16 & 0.15 & 0.19 & 0.09 \\
\hline IS & 0.41 & 0.12 & 0.18 & 0.23 & 0.20 & 0.20 & $\mathbf{0 . 3 4}$ & $\mathbf{0 . 4 0}$ & -0.12 & 0.18 & 0.10 & 0.36 \\
\hline LI & 0.36 & 0.15 & 0.28 & 0.33 & $\mathbf{0 . 3 6}$ & $\mathbf{0 . 5 1}$ & $\mathbf{0 . 6 0}$ & $\mathbf{0 . 5 7}$ & 0.12 & $\mathbf{0 . 2 2}$ & 0.22 & $\mathbf{0}$ \\
\hline BI & 0.22 & 0.02 & 0.16 & 0.13 & 0.20 & $\mathbf{0 . 3 3}$ & $\mathbf{0 . 3 7}$ & $\mathbf{0 . 4 5}$ & 0.00 & 0.02 & -0.04 & 0.00 \\
\hline MO & 0.32 & 0.14 & 0.25 & 0.26 & $\mathbf{0 . 3 8}$ & $\mathbf{0 . 5 0}$ & $\mathbf{0 . 5 0}$ & $\mathbf{0 . 6 1}$ & 0.10 & 0.11 & 0.17 & $\mathbf{0} .21$ \\
\hline
\end{tabular}

Note: Statistically significant at $p<0.01$ (bold) and $p<0.05$ (italic) 


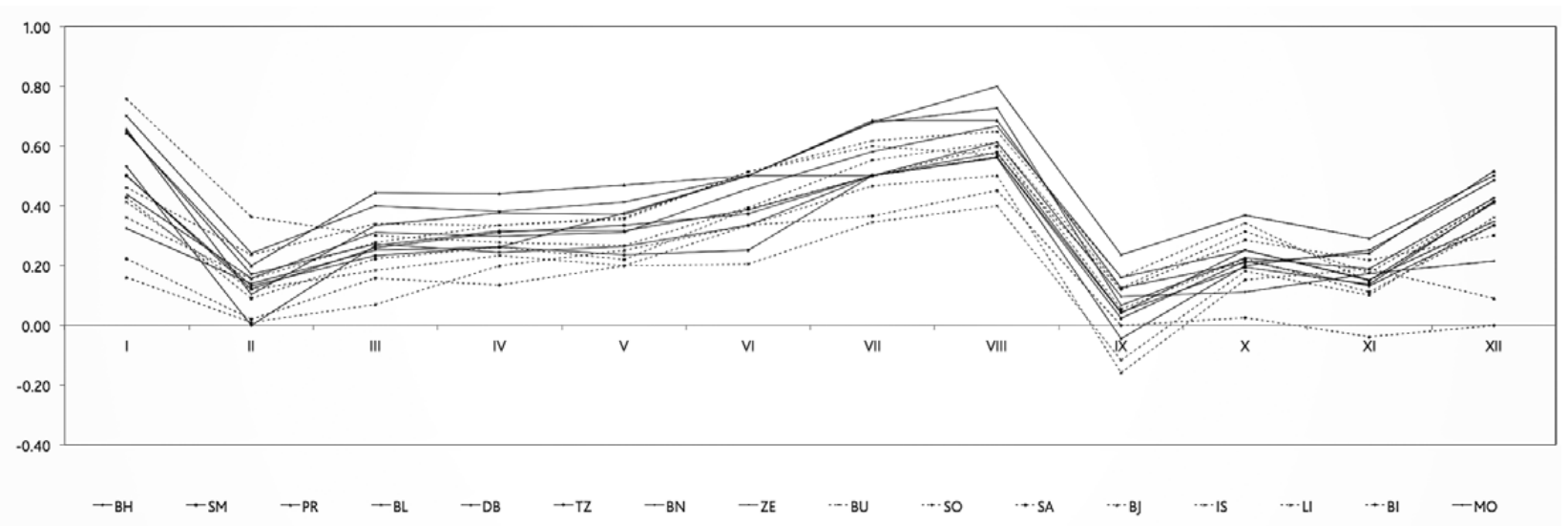

Figure 5. Decadal trends in monthly mean air temperatures in Bosnia and Herzegovina in 1961-2015 ( ${ }^{\circ} \mathrm{C}$ per decade)

the 1961-1990 periods. Comparison of average seasonal temperatures in two observed thirty-year periods also indicated that the most prominent warming was present in the hottest part of the year. The average summer temperature increase exceeded $1^{\circ} \mathrm{C}$ over the entire territory and almost reached $2^{\circ} \mathrm{C}$ in the extreme northeast. Average winter and spring temperatures were also significantly higher $-0.4^{-1.2}{ }^{\circ} \mathrm{C}$ and

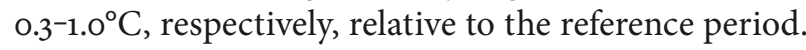
Changes were the least pronounced in autumn. The growing season temperatures were also significantly higher compared to the reference period $\left(0.6^{-}-1.3^{\circ} \mathrm{C}\right)$.

Trend analysis of monthly mean temperatures shows that a positive temperature trend occurs throughout the year, except in some areas in September and November (Table 5 and Figure 5). The most prominent and statistically significant $(\mathrm{p}<0.01)$ warming trend is present in summer months - August, July, and June, during which temperature increased by $0.4^{-0} .8^{\circ} \mathrm{C}, 0.3^{-0} .7^{\circ} \mathrm{C}$, and $0.2^{-}-0.5^{\circ} \mathrm{C}$ per decade, respectively.

A positive trend is also strong and significant during the two coldest months. In January and Decem-

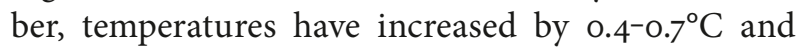
$0.3^{-} 0.5^{\circ} \mathrm{C}$ per decade, respectively in most areas. In these seasons, the trend is less pronounced only in the highest mountain areas and in some regions of Herzegovina. The increase in March and April is mainly significant, whereas changes in autumn months are small and insignificant. A low negative trend is present in some areas in September (Bjelašnica, Ivan Sedlo and Bugojno) and November (Bileća).

Previous studies showed that positive temperature anomalies in many regions of Europe are associated with the EA pattern (Rust, et al., 2015). A research on

Table 6. Pearson correlation coefficient between monthly air temperatures in Bosnia and Herzegovina (state average) and the NAOI, EAI and AOI in the 1961-2015 periods

\begin{tabular}{|c|c|c|c|c|c|c|c|c|c|c|c|c|}
\hline Index & I & II & III & IV & V & VI & VII & VIII & IX & X & XI & XII \\
\hline EAI & $\mathbf{0 . 5 1 1}$ & $\mathbf{0 . 7 5 7}$ & $\mathbf{0 . 3 5 4}$ & $\mathbf{0 . 5 9 1}$ & $\mathbf{0 . 5 9 4}$ & $\mathbf{0 . 3 7 6}$ & $\mathbf{0 . 4 1 4}$ & $\mathbf{0 . 7 2 4}$ & $\mathbf{0 . 6 1 8}$ & $\mathbf{0 . 4 7 5}$ & $\mathbf{0 . 5 0 5}$ & $\mathbf{0 . 3 6 4}$ \\
\hline NAOI & $\mathbf{0 . 4 4 9}$ & 0.180 & 0.250 & -0.053 & -0.023 & -0.329 & -0.270 & -0.172 & 0.102 & -0.240 & -0.254 & 0.277 \\
\hline AOI & 0.215 & 0.242 & 0.339 & -0.033 & 0.015 & -0.195 & -0.204 & 0.097 & $\mathbf{0 . 4 4 2}$ & -0.141 & -0.142 & 0.055 \\
\hline
\end{tabular}

Note: Statistically significant at $p<0.01$ (bold) and $p<0.05$ (italic)

Table 7. Pearson correlation coefficient between seasonal EAI and air temperatures in Bosnia and Herzegovina in the 1961-2015 periods

\begin{tabular}{|c|c|c|c|c|c|c|c|c|c|}
\hline Station & Winter & Spring & Summer & Autumn & Station & Winter & Spring & Summer & Autumn \\
\hline BH & 0.595 & 0.483 & 0.670 & 0.533 & BU & 0.673 & 0.519 & 0.704 & 0.495 \\
\hline SM & 0.607 & 0.461 & 0.670 & 0.495 & SO & 0.690 & 0.447 & 0.655 & 0.437 \\
\hline PR & 0.626 & 0.491 & 0.706 & 0.585 & SA & 0.680 & 0.445 & 0.665 & 0.452 \\
\hline BL & 0.592 & 0.514 & 0.666 & 0.571 & B & 0.612 & 0.373 & 0.655 & 0.515 \\
\hline DB & 0.599 & 0.461 & 0.612 & 0.487 & IS & 0.631 & 0.431 & 0.594 & 0.441 \\
\hline TZ & 0.596 & 0.433 & 0.599 & 0.450 & LI & 0.621 & 0.502 & 0.674 & 0.441 \\
\hline BN & 0.505 & 0.475 & 0.610 & 0.389 & BI & 0.621 & 0.467 & 0.671 & 0.377 \\
\hline ZE & 0.656 & 0.509 & 0.644 & 0.456 & MO & 0.649 & 0.530 & 0.676 & 0.467 \\
\hline
\end{tabular}

Note: Statistically significant at $p<0.01$ (bold) and $p<0.05$ (italic) 

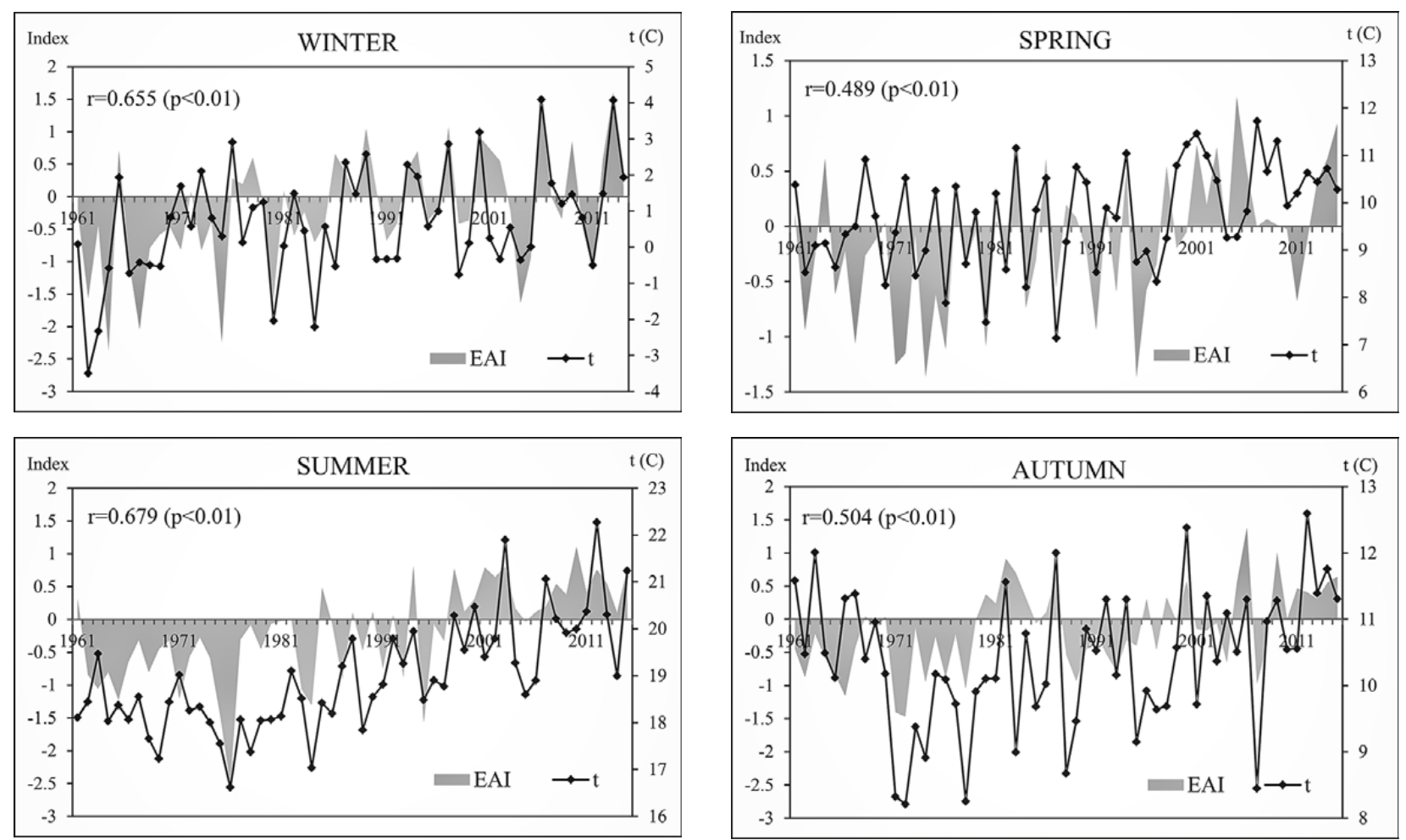

Figure 6. Correlation between seasonal EAI and air temperatures in Bosnia and Herzegovina (state average) in the 1961-2015 periods

linking teleconnection patterns to temperaturein $\mathrm{Eu}-$ rope found positive correlation throughout the year for part of the continent where Bosnia and Herzegovina is located (Rust, et al., 2015). The strong and significant positive correlation between EA pattern index (EAI) and temperature in Bosnia and Herzegovina was determined over the entire territory throughout the year
(Table 6). Although statistically significant correlation was demonstrated in all seasons, the highest correlation coefficients were determined for summer and winter seasons - 0.679 (0.594-0.706) and 0.655 (0.505-0.690), respectively (Figure 6 and Table 7). Throughout the year, the correlation was the highest in February - 0.757 (0.555-0.799) and August - 0.724 (0.652-0.740) (Table 8).

Table 8. Pearson correlation coefficient between monthly EAI and air temperatures in Bosnia and Herzegovina in the 1961-2015 periods

\begin{tabular}{|c|c|c|c|c|c|c|c|c|c|c|c|c|}
\hline Station & 1 & II & III & IV & V & VI & VII & VIII & IX & $x$ & $X I$ & XII \\
\hline $\mathrm{BH}$ & 0.404 & 659 & 0.293 & .608 & .624 & 0.332 & 0.394 & 0.692 & 0.593 & .485 & 0.544 & 0.407 \\
\hline SM & 0.462 & 0.672 & 0.287 & 0.602 & 0.591 & 0.376 & 0.430 & 0.724 & 0.607 & .475 & .490 & .320 \\
\hline PR & 0.463 & 0.680 & 0.326 & 0.579 & 0.551 & 0.388 & 0.496 & 0.706 & 0.544 & 0.561 & 0.504 & 0.416 \\
\hline $\mathrm{BL}$ & 0.432 & 0.668 & 0.309 & 0.616 & 0.551 & 0.356 & 0.423 & 0.740 & 0.602 & 514 & 511 & 0.347 \\
\hline DB & 0.429 & 0.652 & 0.326 & 0.602 & 0.555 & 0.364 & 0.334 & 0.696 & 0.575 & 0.477 & 0.474 & 0.339 \\
\hline $\mathrm{TZ}$ & 0.446 & 0.737 & 0.323 & 0.568 & 0.525 & 0.359 & 0.361 & 0.671 & 0.597 & 0.465 & 0.474 & 0.325 \\
\hline $\mathrm{BN}$ & 0.408 & 0.555 & 0.332 & 0.561 & 0.524 & 0.317 & 0.444 & 0.671 & 0.517 & 0.421 & 0.441 & 0.323 \\
\hline ZE & 0.453 & 0.772 & 0.382 & 0.585 & 0.584 & 0.318 & 0.395 & 0.713 & 0.619 & 0.448 & 0.411 & 0.295 \\
\hline$B U$ & 0.461 & 0.783 & 0.369 & 0.611 & 0.588 & 0.375 & 0.422 & 0.729 & 0.611 & 0.421 & 0.442 & 0.295 \\
\hline SO & 0.502 & 0.785 & 0.281 & 0.599 & 0.559 & 0.335 & 0.383 & 0.690 & 0.544 & 0.357 & 0.438 & 0.371 \\
\hline SA & 0.503 & 0.795 & 0.366 & 0.585 & 0.540 & 0.379 & 0.344 & 0.719 & 0.585 & 0.429 & 0.437 & 0.278 \\
\hline BJ & 0.635 & 0.779 & 0.395 & 0.457 & 0.566 & 0.359 & 0.285 & 0.721 & 0.555 & 0.460 & 0.656 & 0.417 \\
\hline IS & 0.516 & 0.799 & 0.357 & 0.545 & 0.578 & 0.398 & 0.247 & 0.652 & 0.583 & 0.432 & 0.495 & 0.345 \\
\hline LI & 0.465 & 0.771 & 0.359 & 0.539 & 0.615 & 0.316 & 0.444 & 0.713 & 0.633 & 0.395 & 0.466 & 0.302 \\
\hline $\mathrm{BI}$ & 0.607 & 0.782 & 0.402 & 0.504 & 0.597 & 0.431 & 0.360 & 0.665 & 0.632 & 0.402 & 0.420 & 0.175 \\
\hline $\mathrm{MO}$ & 0.599 & 0.758 & 0.396 & 0.488 & 0.629 & 0.377 & 0.426 & 0.681 & 0.655 & 0.456 & 0.451 & 0.292 \\
\hline
\end{tabular}

Note: Statistically significant at $p<0.01$ (bold) and $p<0.05$ (italic) 

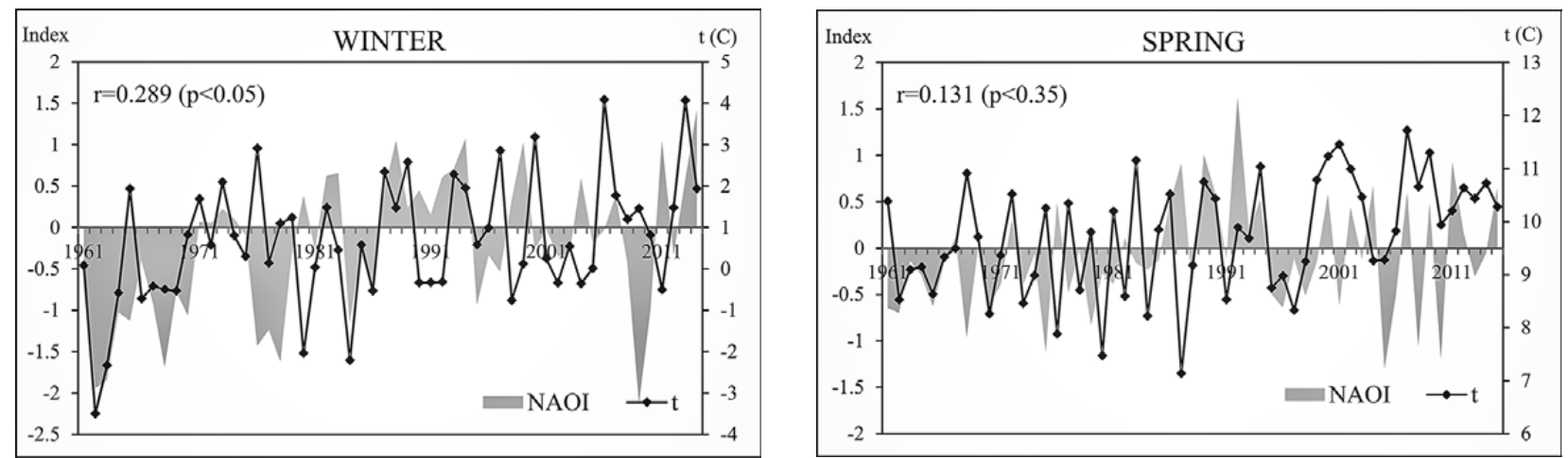

Figure 7. Correlation between winter and spring NAOI and air temperatures in Bosnia and Herzegovina (state average) in the 1961-2015 periods

Climate variability in Europe strongly dictates NAO, especially during winter season (Hurrell, et al., 2003). In winter, during positive NAO phase, the warmer maritime air masses are advected to Europe by stronger-than-average westerlies over the middle latitudes associated with low pressure anomalies over the region of the Icelandic low and anomalously high pressures across the subtropical Atlantic (Rust, et al., 2015; Hurrell, et al., 2003). Studies showed that the persistent and exceptionally strong positive NAO index (NAOI) since the early 1980 o accounted for a substantial part of the observed warming over Europe in winter (Hurrell, Van Loon, 1997). In Bosnia and Herzegovina, the significant positive correlation between NAOI and temperature was determined in winter season (Figure 7). The correlation is much stronger in the Peripannonian region, in the northern part of the territory (0.303-0.402) (Table 9). The correlation coefficients were highest in January (0.234-0.594). This correlation is statistically significant over almost the entire territory. The positive correlation was also found in December (statistically significant in the northern part of the territory), March (significant only in some areas), February and September (both insignificant) (Table 10). The NAO influence on the temperature during winter months as well as during September was also demonstrated by previous studies for other areas in this part of Europe (e.g. Serbia) (Pavlović Berdon, 2012).The weak and insignificant positive correlation between NAOI and temperatures in Bosnia and Herzegovina was also found in spring.

Studies have proved that during the period of instrumental measurements (since the mid-19th century), sea surface temperatures in North Atlantic showed two $65^{-80}$ years cycles with a $0.4^{\circ} \mathrm{C}$ temperature range between extremes of positive/warm and negative/cool phases referred to as the Atlantic Multidecadal Oscillation (AMO) (Gray, et al., 2004). The AMO index (AMOI) is positively correlated with the global mean annual surface land temperature (correlation coefficient value is $0.65 \pm 0.04$ ) (Muller, et al., 2013). Alexander, et al. (2014) demonstrated that AMO has been in its warm phase since 1995. Since then, the temperature increase also becomes more pronounced in Bosnia and Herzegovina. The correlation analysis showed that summer and autumn temperatures in Bosnia and Herzegovina were significantly positively related with AMOI (Figure 8) -the correlation in spring was negligible. The links between AMOI and temperatures are particularly strong and positive during summer months July, June, and August - 0.618, 0.388, and 0.329, respectively, and then in October (0.329) and April (o.272) (Table 11).

Table 9. Pearson correlation coefficient between seasonal NAOI and air temperatures in Bosnia and Herzegovina in the 1961-2015 periods

\begin{tabular}{|c|c|c|c|c|c|c|c|c|c|}
\hline Station & Winter & Spring & Summer & Autumn & Station & Winter & Spring & Summer & Autumn \\
\hline $\mathrm{BH}$ & 0.335 & 0.091 & -0.426 & -0.232 & $\mathrm{BU}$ & 0.250 & 0.116 & -0.447 & -0.208 \\
\hline SM & 0.324 & 0.111 & -0.401 & -0.165 & so & 0.202 & 0.102 & -0.398 & -0.156 \\
\hline PR & 0.382 & 0.191 & -0.420 & -0.088 & SA & 0.176 & 0.086 & -0.487 & -0.170 \\
\hline$B L$ & 0.397 & 0.157 & -0.438 & -0.177 & BJ & 0.096 & 0.073 & -0.478 & -0.001 \\
\hline $\mathrm{DB}$ & 0.327 & 0.126 & -0.417 & -0.133 & IS & 0.250 & 0.081 & -0.353 & -0.105 \\
\hline $\mathrm{TZ}$ & 0.303 & 0.080 & -0.477 & -0.144 & $\mathrm{LI}$ & 0.210 & 0.196 & -0.407 & -0.163 \\
\hline $\mathrm{BN}$ & 0.402 & 0.151 & -0.409 & -0.141 & $\mathrm{BI}$ & 0.057 & 0.133 & -0.411 & -0.040 \\
\hline ZE & 0.214 & 0.110 & -0.434 & -0.164 & MO & 0.257 & 0.214 & -0.376 & 0.022 \\
\hline
\end{tabular}

Note: Statistically significant at $p<0.01$ (bold) and $p<0.05$ (italic) 
Table 10. Pearson correlation coefficient between monthly NAOI and air temperatures in Bosnia and Herzegovina in the 1961-2015 periods

\begin{tabular}{|c|c|c|c|c|c|c|c|c|c|c|c|c|}
\hline Station & I & II & III & IV & V & VI & VII & VIII & IX & X & XI & XII \\
\hline BH & $\mathbf{0 . 4 5 7}$ & 0.163 & 0.240 & -0.070 & -0.072 & $-\mathbf{0 . 3 2 8}$ & -0.230 & -0.167 & 0.077 & -0.288 & -0.299 & $\mathbf{0 . 3 7 1}$ \\
\hline SM & $\mathbf{0 . 4 6 4}$ & 0.225 & 0.233 & -0.071 & -0.064 & -0.311 & -0.194 & -0.146 & 0.142 & -0.215 & -0.312 & 0.304 \\
\hline PR & $\mathbf{0 . 4 9 7}$ & 0.235 & 0.290 & -0.044 & -0.041 & -0.296 & -0.200 & -0.202 & 0.077 & -0.162 & -0.280 & $\mathbf{0} .362$ \\
\hline BL & $\mathbf{0 . 5 1 0}$ & 0.254 & 0.268 & 0.003 & -0.039 & $-\mathbf{0 . 3 4 2}$ & -0.246 & -0.128 & 0.070 & -0.264 & -0.289 & $\mathbf{0} .382$ \\
\hline DB & $\mathbf{0 . 5 2 9}$ & 0.198 & 0.228 & -0.056 & -0.016 & -0.290 & -0.266 & -0.123 & 0.095 & -0.202 & -0.282 & 0.340 \\
\hline TZ & $\mathbf{0 . 4 8 6}$ & 0.162 & 0.215 & -0.124 & 0.005 & $-\mathbf{0 . 3 5 5}$ & -0.306 & -0.130 & 0.128 & -0.212 & -0.288 & 0.315 \\
\hline BN & $\mathbf{0 . 5 9 4}$ & 0.143 & 0.266 & -0.013 & -0.050 & -0.319 & -0.262 & -0.064 & 0.107 & -0.241 & -0.283 & $\mathbf{0} .370$ \\
\hline ZE & $\mathbf{0 . 3 8 4}$ & 0.166 & 0.237 & -0.068 & -0.014 & $-\mathbf{0 . 3 5 6}$ & -0.267 & -0.153 & 0.105 & -0.236 & -0.292 & 0.183 \\
\hline BU & $\mathbf{0 . 3 6 5}$ & 0.150 & 0.247 & -0.063 & -0.043 & $-\mathbf{0 . 3 5 3}$ & -0.298 & -0.210 & 0.087 & -0.308 & -0.311 & 0.189 \\
\hline SO & $\mathbf{0 . 3 5 4}$ & 0.147 & 0.193 & -0.082 & -0.027 & $-\mathbf{0 . 3 5 3}$ & -0.188 & -0.234 & 0.049 & -0.286 & -0.210 & 0.128 \\
\hline SA & $\mathbf{0 . 3 1 9}$ & 0.124 & 0.231 & -0.092 & -0.028 & $-\mathbf{0 . 4 0 0}$ & -0.328 & -0.210 & 0.095 & -0.262 & -0.324 & 0.141 \\
\hline BJ & 0.243 & 0.117 & 0.112 & -0.071 & -0.046 & -0.324 & -0.304 & -0.241 & 0.097 & -0.196 & 0.038 & 0.202 \\
\hline IS & $\mathbf{0 . 3 9 4}$ & 0.156 & 0.221 & -0.072 & -0.006 & -0.199 & -0.211 & -0.187 & 0.112 & -0.231 & -0.201 & 0.260 \\
\hline LI & $\mathbf{0 . 3 6 9}$ & 0.119 & 0.311 & 0.009 & -0.003 & -0.298 & -0.253 & -0.149 & 0.107 & -0.232 & -0.137 & 0.216 \\
\hline BI & 0.234 & 0.160 & 0.227 & -0.016 & 0.045 & -0.307 & -0.273 & -0.179 & 0.095 & -0.167 & -0.143 & -0.054 \\
\hline MO & $\mathbf{0 . 4 0 4}$ & 0.246 & $\mathbf{0 . 3 6 1}$ & 0.041 & 0.040 & -0.208 & -0.219 & -0.131 & 0.119 & -0.078 & -0.075 & 0.179 \\
\hline
\end{tabular}

Note: Statistically significant at $p<0.01$ (bold) and $p<0.05$ (italic)
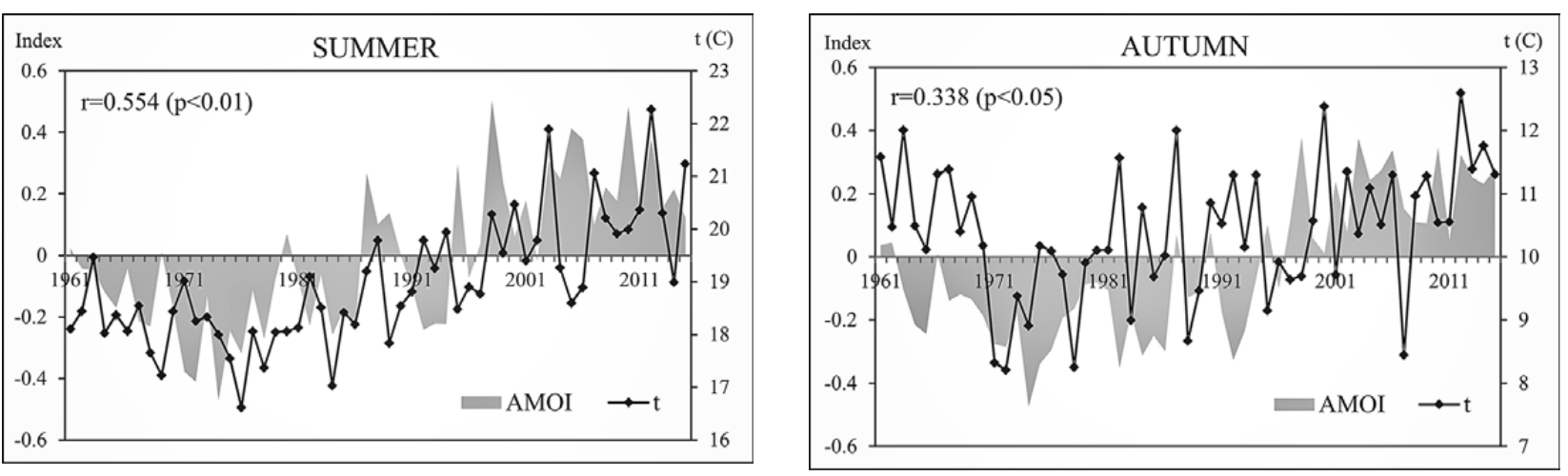

Figure 8. Correlation between summer and autumn AMOI and temperatures in Bosnia and Herzegovina (state average) in the 1961-2015 periods

In winter and spring seasons, in addition to the positive correlations with the primary modes of atmospheric circulation variability over the North Atlantic, the positive correlation between the temperatures and the Arctic Oscillation index (AOI) was also determined (Figure 9). In spring, the calculated correlation coefficients that were in the range of $0.339^{-0} 0.509$ are significant over the entire territory of Bosnia and Herzegovina (Table 12).
The winter season showed insignificant correlation, somewhat higher in the northern part of the territory (in other areas negligible). The positive correlation was found in the December-March and August-September periods (Table 13).The correlation coefficients were the highest in September $\left(0.341^{-0.568,} \mathrm{p}<0.01\right)$ and March (0.258-0.441, $\mathrm{p}<0.05$ at most stations), and then in February and January (0.135-0.331 and $0.089^{-0} 0.330$, respectively, only partially significant). Similar results were obtained in Serbia (Pavlović Berdon, 2012).

Table 11. Pearson correlation coefficients between monthly AMOI and air temperatures in Bosnia and Herzegovina (state average) in the 1961-2015 periods

\begin{tabular}{|c|c|c|c|c|c|c|c|c|c|c|c|}
\hline I & II & III & IV & V & VI & VII & VIII & IX & X & XI & XII \\
\hline-0.012 & 0.057 & -0.095 & 0.272 & 0.075 & $\mathbf{0 . 3 8 8}$ & $\mathbf{0 . 6 1 8}$ & 0.329 & 0.125 & 0.329 & 0.166 & -0.076 \\
\hline
\end{tabular}

Note: Statistically significant at $p<0.01$ (bold) and $p<0.05$ (italic) 

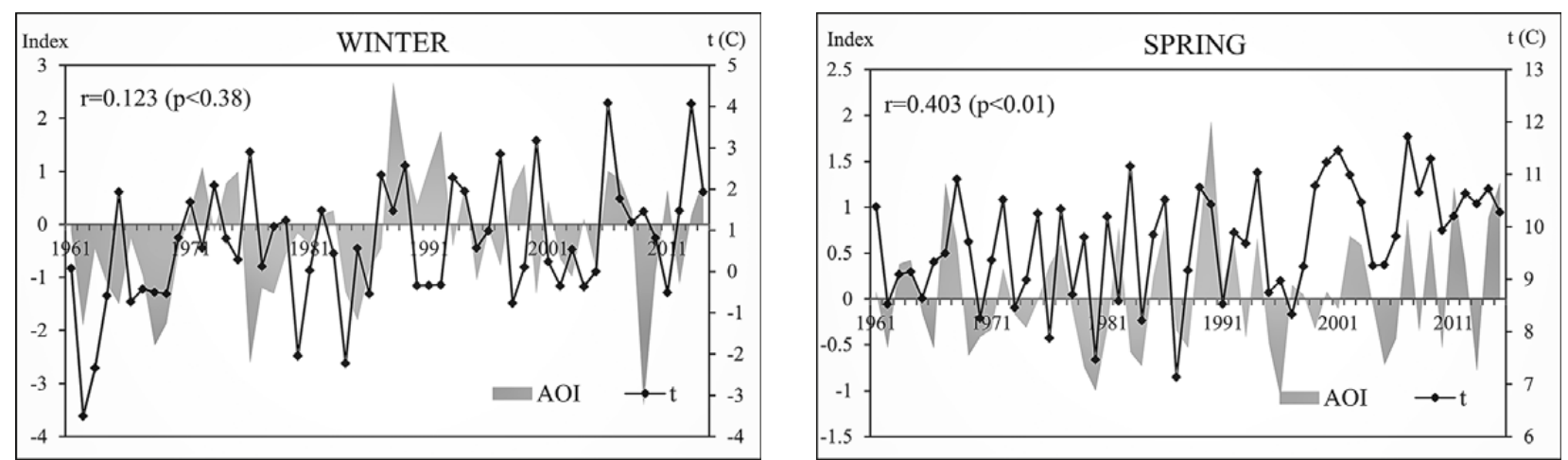

Figure 9. Correlation between winter and spring $\mathrm{AOI}$ and air temperatures in Bosnia and Herzegovina (state average) in the 1961-2015 periods

Table 12. Pearson correlation coefficient between seasonal AOI and air temperatures in Bosnia and Herzegovina in the 1961-2015 periods

\begin{tabular}{|c|c|c|c|c|c|c|c|c|c|}
\hline Station & Winter & Spring & Summer & Autumn & Station & Winter & Spring & Summer & Autumn \\
\hline BH & 0.194 & $\mathbf{0 . 3 7 7}$ & -0.179 & -0.168 & BU & 0.047 & $\mathbf{0 . 3 7 7}$ & -0.171 & -0.139 \\
\hline SM & 0.150 & $\mathbf{0 . 3 7 2}$ & -0.124 & -0.157 & SO & 0.000 & $\mathbf{0 . 3 4 5}$ & -0.150 & -0.077 \\
\hline PR & 0.217 & $\mathbf{0 . 3 8 4}$ & -0.140 & -0.045 & SA & 0.001 & $\mathbf{0 . 3 4 5}$ & -0.221 & -0.099 \\
\hline BL & 0.205 & $\mathbf{0 . 3 7 1}$ & -0.168 & -0.096 & BJ & 0.066 & $\mathbf{0 . 3 3 9}$ & -0.232 & 0.130 \\
\hline DB & 0.153 & $\mathbf{0 . 3 9 6}$ & -0.203 & -0.120 & IS & 0.122 & $\mathbf{0 . 3 4 6}$ & -0.169 & -0.029 \\
\hline TZ & 0.126 & $\mathbf{0 . 3 6 8}$ & -0.226 & -0.158 & LI & 0.083 & $\mathbf{0 . 4 5 8}$ & -0.115 & -0.039 \\
\hline BN & 0.210 & $\mathbf{0 . 4 1 9}$ & -0.143 & -0.094 & BI & 0.030 & $\mathbf{0 . 4 3 9}$ & -0.119 & 0.083 \\
\hline ZE & 0.005 & $\mathbf{0 . 3 8 8}$ & -0.174 & -0.105 & MO & 0.179 & $\mathbf{0 . 5 0 9}$ & -0.050 & 0.217 \\
\hline
\end{tabular}

Note: Statistically significant at $p<0.01$ (bold) and $p<0.05$ (italic)

Table 13. Pearson correlation coefficient between monthly AOI and air temperatures in Bosnia and Herzegovina in the 1961-2015 periods

\begin{tabular}{|c|c|c|c|c|c|c|c|c|c|c|c|c|}
\hline Station & I & II & III & IV & V & VI & VII & VIII & IX & X & XI & XII \\
\hline BH & 0.242 & 0.246 & 0.340 & -0.094 & -0.009 & -0.195 & -0.197 & 0.074 & $\mathbf{0 . 3 4 1}$ & -0.172 & -0.139 & 0.113 \\
\hline SM & 0.184 & 0.283 & 0.294 & -0.079 & -0.004 & -0.172 & -0.131 & 0.105 & $\mathbf{0 . 3 9 3}$ & -0.162 & -0.189 & 0.076 \\
\hline PR & 0.220 & 0.312 & 0.337 & -0.069 & 0.014 & -0.119 & -0.163 & 0.057 & $\mathbf{0 . 4 7 4}$ & -0.089 & -0.156 & 0.153 \\
\hline BL & 0.246 & 0.304 & 0.321 & 0.005 & -0.012 & -0.208 & -0.179 & 0.130 & $\mathbf{0 . 3 9 3}$ & -0.173 & -0.136 & 0.118 \\
\hline DB & 0.236 & 0.281 & 0.304 & -0.041 & -0.016 & -0.179 & -0.215 & 0.085 & $\mathbf{0 . 3 7 5}$ & -0.155 & -0.172 & 0.093 \\
\hline TZ & 0.247 & 0.208 & 0.304 & -0.095 & 0.023 & -0.269 & -0.235 & 0.107 & $\mathbf{0 . 4 0 5}$ & -0.168 & -0.166 & 0.085 \\
\hline BN & 0.330 & 0.208 & 0.344 & -0.064 & 0.025 & -0.179 & -0.166 & 0.154 & $\mathbf{0 . 4 0 2}$ & -0.128 & -0.121 & 0.110 \\
\hline ZE & 0.090 & 0.203 & 0.319 & -0.048 & 0.049 & -0.213 & -0.187 & 0.086 & $\mathbf{0 . 4 2 4}$ & -0.177 & -0.199 & -0.030 \\
\hline BU & 0.115 & 0.185 & 0.338 & -0.025 & -0.018 & -0.201 & -0.226 & 0.081 & $\mathbf{0 . 4 1 2}$ & -0.226 & -0.213 & -0.017 \\
\hline SO & 0.089 & 0.135 & 0.294 & -0.041 & 0.009 & -0.212 & -0.217 & 0.053 & $\mathbf{0 . 3 7 0}$ & -0.154 & -0.144 & -0.035 \\
\hline SA & 0.100 & 0.173 & 0.321 & -0.057 & -0.029 & -0.252 & -0.288 & 0.078 & $\mathbf{0 . 4 0 7}$ & -0.170 & -0.209 & -0.077 \\
\hline BJ & 0.280 & 0.198 & 0.258 & 0.005 & -0.014 & -0.223 & -0.242 & 0.028 & $\mathbf{0 . 4 1 7}$ & -0.061 & 0.119 & 0.099 \\
\hline IS & 0.236 & 0.232 & 0.315 & -0.024 & -0.034 & -0.139 & -0.219 & 0.035 & $\mathbf{0 . 3 7 2}$ & -0.109 & -0.083 & 0.016 \\
\hline LI & 0.151 & 0.197 & $\mathbf{0 . 4 0 1}$ & 0.022 & 0.042 & -0.160 & -0.154 & 0.142 & $\mathbf{0 . 4 7 9}$ & -0.160 & -0.144 & 0.048 \\
\hline BI & 0.211 & 0.222 & 0.338 & 0.048 & 0.070 & -0.175 & -0.142 & 0.092 & $\mathbf{0 . 4 9 9}$ & -0.036 & -0.102 & -0.107 \\
\hline MO & 0.252 & 0.331 & $\mathbf{0 . 4 4 1}$ & 0.072 & 0.126 & -0.092 & -0.113 & 0.173 & $\mathbf{0 . 5 6 8}$ & 0.072 & 0.002 & 0.109 \\
\hline
\end{tabular}

Note: Statistically significant at $p<0.01$ (bold) and $p<0.05$ (italic) 


\section{Conclusion}

Global warming has been one of the most pertinent observed changes of the climate system since the second half of the 2oth century. The paper addresses mean air temperature changes in Bosnia and Herzegovina during 1961-2015 periods. The main conclusions of this study are as follows:

- The obtained results indicate that during the observed 1961-2015 periods, the entire territory of Bosnia and Herzegovina is characterized by prominent and significant $(\mathrm{p}<0.01)$ annual warming. The annual temperature increase was in the range of $0.2^{-} 0.5^{\circ} \mathrm{C}$ per decade. All stations present a high positive and significant $(\mathrm{p}<0.01)$ seasonal trend in summer (the strongest in August), when the temperature increased by $0.5^{-} 0.6^{\circ} \mathrm{C}$ per decade at majority of stations. The estimated winter and spring temperature trends are mostly significant $(\mathrm{p}<0.01$ or $\mathrm{p}<0.05$ ) with the highest frequency of increase in the range of $0.3^{-} 0.5^{\circ} \mathrm{C}$ and $0.2^{-} 0.4^{\circ} \mathrm{C}$ per decade, respectively. Trend magnitudes are smaller and generally insignificant only in Bileća and Bjelašnica area. In autumn, low positive and mainly insignificant trends prevail. A low negative trend is found only in Bileća area.

- Although positive trends are present in almost all months, warming is most pronounced in June-August and December-January periods. The temperature increase in April and May is also mostly significant. In the February-March and especially September-November periods, low and insignificant trends dominate. A low trend of the opposite sign is present in some areas in September and November.

- In general, the highest warming trends were observed over the northern part of the territory and in Sokolac area, whereas the high mountainous areas of Herzegovina were characterized by the lowest temperature increase.

- The observed temperature trends in Bosnia and Herzegovina are related with certain Northern Hemisphere teleconnection patterns. Significant correlation between EAI and temperature was demonstrated in all seasons over the entire territory. Winter temperatures were also significantly influenced by the NAO (particularly in the northern part of the territory), whiles spring temperatures were positively correlated with the AO.

- The results obtained in this survey are in concordance with and similar to the results of other studies related to recent trends in air temperature in the adjacent regions of Southeast Europe.

- The observed and projected temperature change will certainly have numerous and diverse positive and negative impacts on key sectors in Bosnia and Herzegovina, such as agriculture, forestry, hydropower, tourism, human health, biodiversity and sensitive ecosystems, etc. (Radusin, et al., 2013). Further studies on impacts of the observed temperature trends on the natural and socio-economic systems, which become globally important issues, are certainly necessary.

\section{References}

Alexander, L. V., Zhang, X., Peterson, T. C., Caesar, J., Gleason, B., Klein Tank, A. M. G., Haylock, M., Collins, D., Trewin, B., Rahimzadeh, F., Tagipour, A., Rupa Kumar, K., Revadekar, J., Griffiths, G., Vincent, L., Stephenson, D. B., Burn, J., Aguilar, E., Brunet, M., Taylor, M., New, M., Zhai, P., Rusticucci, M., Vazquez-Aguirre, J. L. 2006. Global Observed Changes in Daily Climate Extremes of Temperature and Precipitation. Journal of Geophysical Research, 111, Do5109.

Alexander, M. A., Halimeda Kilbourne, K., Nye, J. A. 2014. Climate Variability during Warm and Cold Phases of the Atlantic Multidecadal Oscillation (AMO) 18712008. Journal of Marine Systems,133, 14-26.

Bajat, B., Blagojević, D., Kilibarda, M., Luković, J., Tošić, I. 2015. Spatial Analysis of the Temperature Trends in Serbia during the Period 1961-2010. Theoretical and Applied Climatology, 121, 1, 289-301.

Branković, Č., Cindrić, K., Gajić-Čapka, M., Güttler, I., Pandžić, K., Patarčić, M., Srnec, L., Tomašević, I., Vučetić, V., Zaninović, K. 2013. Sixth National Communication of the Republic of Croatia under the United Nation Framework Convention on the Climate Change (UNFCCC), Collection of papers, pp.131.

Burić, D., Ducić, V., Mihajlović, J., Luković, J., Dragojlović, J. 2014. Recent Extreme Air Temperature Changes in Montenegro. Bulletin of the Serbian Geographical Society, XCIV, 3, 1-14.

Ducić, V., Luković, J., Milovanović, B. 2009. Changes in Temperature and Precipitation in Serbia in the Second Half of the 2oth Century Within the Global Climate Change. Zaštita prirode, LX, 1-2, 641-652. (in Serbian)

Ducić, V., Savić, S., Luković, J. 2008. Contemporary Temperature Changes at the Ground Surface and in the Troposphere over Vojvodina, Serbia. Geographica Pannonica, 12, 2, 56-61.

Fei, J., Zhaohua, W., Jianping, H., Chassignet, E. P. 2014. Evolution of Land Surface Air Temperature Trend. Nature Climate Change, 4, 462-466.

Foster, G., Rahmstorf, S. 2011. Global Temperature Evolution 1979-2010. Environmental Research Letters, 6, 4, 044022. 
Gray, S. T., Graumlich, L. J., Betancourt, J. L., Pederson, G. T. 2004. A Tree-Ring Based Reconstruction of the Atlantic Multidecadal Oscillation since 1567 A.D. Geophysical Research Letters, 31, L12205.

Hansen, J., Sato, M., Ruedy, R., Lo, K., Lea, D.W., Medina-Elizade, M. 2006. Global Temperature Change. Proceedings of the National Academy of Sciences of the United States of America, 103, 39, 14288-14293.

Hartmann, D. L., Klein Tank, A. M. G., Rusticucci, M., Alexander, L. V., Brönnimann, S., Charabi, Y., Dentener, F. J., Dlugokencky, E. J., Easterling, D. R., Kaplan, A., Soden, B. J., Thorne, P. W., Wild, M., Zhai, P. M. 2013. Observations: Atmosphere and Surface. In: Stocker, T. F., Qin, D., Plattner, G. K., Tignor, M., Allen, S. K., Boschung, J., Nauels, A., Xia, Y., Bex, V., Midgley, P. M. [eds.], Climate Change 2013: The Physical Science Basis. Contribution of Working Group I to the Fifth Assessment Report of the Intergovernmental Panel on Climate Change. Cambridge University Press, Cambridge, United Kingdom and New York, NY, USA, pp. 159-254.

Hurrell, J., Van Loon, H. 1997. Decadal Variations in Climate Associated with the North Atlantic Oscillation. Climatic Change, 36, 3, 301-326.

Hurrell, J. W., Kushnir, Y., Ottersen, G., Visbeck, M. 2003. An Overview of the North Atlantic Oscillation. In: Hurrell, J. W., Kushnir, Y., Ottersen, G., Visbeck, M. [eds.]. The North Atlantic Oscillation: Climatic Significance and Environmental Impact. American Geophysical Union, Washington, D.C., pp. 1-35.

IPCC 2014. Climate Change 2014: Synthesis Report. Contribution of Working Groups I, II and III to the Fifth Assessment Report of the Intergovernmental Panel on Climate Change [Core Writing Team, Pachauri, R.K., Meyer, L.A. (eds.)]. IPCC, Geneva, Switzerland, pp.151.

Klein Tank, A. M. G., Können, G. P. 2003. Trends Indices of DailyTemperature and Precipitation Extremes in Europe, 1946-99. Journal of Climate, 16, 22, 3665-3680.

Kovats, R. S., Valentini, R., Bouwer, L. M., Georgopoulou, E., Jacob, D., Martin, E., Rounsevell, M., Soussana, J. F.2014. Europe. In: Barros, V. R., Field, C. B., Dokken, D. J., Mastrandrea, M. D., Mach, K. J., Bilir, T. E., Chatterjee, M., Ebi, K. L.,Estrada, Y. O., Genova, R. C., Girma, B., Kissel, E. S., Levy, A. N., MacCracken, S., Mastrandrea, P. R., White, L. L.[eds.].Climate Change 2014: Impacts, Adaptation, and Vulnerability. Part B: Regional Aspects. Contribution of Working Group II to the Fifth Assessment Report of the Intergovernmental Panel on Climate Change. Cambridge University Press, Cambridge, United Kingdom and New York, NY, USA, pp. 1267-1326.
Luterbacher, J., Dietrich, D., Xoplaki, E., Grosjean, M., Wanner, H. 2004. European Seasonal and Annual Temperature Variability, Trends, and Extremes since 1500. Science, 303, 1499-1503.

Mamara, A., Argiriou, A. A., Anadranistakis, M. 2016. Recent Trend Analysis of Mean Air Temperature in Greece Based on Homogenized Data. Theoretical and Applied Climatology, 126, 3, 543-573.

Milošević, D., Savić, S., Žiberna, I. 2013. Analysis of the Climate Change in Slovenia: Fluctuations of Meteorological Parameters for the Period 1961-2011 (Part I). Bulletin of the Serbian Geographical Society, 93, 1, 1-14.

Muller, R. A., Curry, J., Groom, D., Jacobsen, R., Perlmutter, S., Rohde, R., Rosenfeld, A., Wickham, C., Wurtele, J. 2013. Decadal Variations in the Global Atmospheric Land Temperatures. Journal of Geophysical Research: Atmospheres, 118, 11, 5280-5286.

NOAA 2016. State of the Climate: Global Analysis for Annual 2015. Available online: http://www.ncdc. noaa.gov/sotc/global/201513 (18.02. 2016)

NOAA NWS CPC 2017. Northern Hemisphere Teleconnection Patterns. Available online: http://www. cpc.ncep.noaa.gov/data/teledoc/telecontents.shtml (28.01. 2017)

Pavlović Berdon, N. 2012. The Impact of Arctic and North Atlantic Oscillation on Temperature and Precipitation Anomalies in Serbia. Geographica Pannonica, 16, 2, 44-55.

Popov, T., Trbić, G. 2015. The Air Temperature Analysis of the Continental Biogeographical Region in the Republic of Srpska. 4th Serbian Congress of Geographers with international participation "Achievements, Current Topics and Challenges of Geographical Science and Practice", Collection of papers (Book1), pp. 115-120. (in Serbian)

Popov, T., Živak, N. 2016. Potential Effects of Recent Climate Change on Agricultural Production in Semberija. 6th International Academic Symposium Local Self-Government in Planning and Regulation of Space and Settlements: Towards European Integration, Collection of papers, pp. 381-388. (in Serbian)

Radusin, S., Oprašić, S., Cero, M., Abdurahmanović, I., Vukmir, G., Knežević, A., Kaplina, A., Husika, A., Carrington, D., Arnautović Aksić, D., Jordan, G., Trbić, G., Stritih, J., Tabaković, L., Kotur, M., Cupać, R. 2013. Climate Change Adaptation and Low-Emission Development Strategy for Bosnia and Herzegovina. Ministry of Foreign Trade and Economic Relations, Federal Ministry of Environment and Tourism, Ministry of Physical Planning, Civil Engineering and Ecology of Republic of Srpska, UNDP, GEF, Sarajevo, pp. 82. 
Rust, H. W., Richling, A., Bissolli, P., Ulbrich, U. 2015. Linking Teleconnection Patterns to European Temperature - A Multiple Linear Regression Model. Meteorologische Zeitschrift, 24, 4, 411-423.

Salmi, T., Määttä, A., Anttila, P., Ruoho-Airola, T., Amnell, T. 2002. Detecting Trends of Annual Values of Atmospheric Pollutants by the Mann-Kendall Test and Sen's Slope Estimates - The Excel Template Application MAKESENS. Publications on air quality, No. 31, Finnish Meteorological Institute, Helsinki, pp. 35.

Trbić, G. 2013. Climate Variations in the Republic of Srpska. In: Gnjato, R. 2oth anniversary of the Republic of Srpska Geographical Society 1993-2013, Collection of papers, pp. 87-95. (in Serbian with English summary)
Trbić, G., Bajić, D. 2011. Specifics of the Climate Change in the Republic of Srpska and Adaptation Options. 3rd Congress of Serbian Geographers with international participation, Collection of papers, pp. 149-157. (in Serbian with English summary)

\section{Other sources}

Intertet 1: https://www.wmo.int/media/content/2015hottest-year-record\#overlay-context $\mathrm{fr}$ / content $/ 1 \% \mathrm{E} 2 \% 80 \% 990 \mathrm{omm}$-confirme-2015est-lann\% $\mathrm{C}_{3} \%$ Age-la-plus-chaude-jamaisenregistr\%C3\%A9e (25.01.2016) WMO 2016. 2015 is Hottest Year on Record.

***1963-1988. Meteorological Yearbook I 1961-1985 Federal Hydrometeorological Institute, Belgrade ***2013-2016. Meteorological Yearbook 1992-2015. Federal Hydrometeorological Institute, Sarajevo 